\title{
DEVELOPMENT OF A SOLAR PANEL AUXILIARY SYSTEM IN ORDER TO EXTEND RANGE
}

\author{
Tibor TÓTH \\ Óbuda University, Bánki Donát Faculty of Mechanical and Safety Engineering, Budapest, Hungary, \\ tothtibi100@gmail.com
}

\begin{abstract}
The aim of this research is to find a solution that can contribute to the more widespread use of electric vehicles and, through development, promote the use of renewable energy sources. It aims to eliminate the disadvantages of electric vehicles, such as self-discharge, stationary charging and limited range. The focus is mainly a solar-powered solution, since small solar cells have already been implemented on the commercially available Nissan Leaf model to solve similar problems but with very little or no improvement. Encouraged by this attempt I have engineered a larger, more useful auxiliary solar cell system to improve the range of these vehicles.
\end{abstract}

Keywords: solar panel, range extension, electric car.

\section{Tools and methodology of research}

The energy consumption levels of electric vehicles are very high, therefore in order to create an alternative charging system, and given that the amount of solar radiation in Hungary is about $1 \mathrm{~kW} / \mathrm{nm}^{2}$, I have chosen solar energy. First I studied the broad topic of solar energy, followed by investigations into the build and functioning of electric vehicles. As a starting point for this research I considered the energy output modelled on the basis of the performance of a solar panel recently installed on our family home. This domestic system has 14 solar panels and yields $4 \mathrm{~kW}$, while on the roof of the vehicle only one such panel can be fitted, therefore I based my calculations on the corresponding energy output of a single panel and analyzed the possibilities for a Nissan Leaf $30 \mathrm{kWh}$ vehicle within the usual Budapest traffic conditions. I compared the results with the energy Photovoltaic database used for the solar system installation. Based on both the theoretical results and the practical measurements this resulted in a universally applicable charging system for electric vehicles, capable of charging not only stationary vehicles, but also moving ones. For modelling, I have designed a complete system that can add, according to my calculations, an av- erage extra $5.7 \mathrm{~km}$ to the car's daily range. During the engineering phase I chose the LG neon2 - 375 W solar panel, a compatible IQ6 plus inverter and a BSR converter. The parameters of these three main components determined the energy yield of the system. The success and the argumentation of this research was advanced by the recently introduced Toyota Prius Plug-in hybrid model which utilizes a similar solution.

\section{Problems during research}

During the research, a solution was needed to fit the system to the vehicle, so I developed a solution that has 3 main components and can be fitted to the electric car without loss of warranty using the existing connection points. I had to solve the security component of the design using the appropriate touch protection and good quality parts to provide easy assembly that can contribute to widespread use of the system. I also had to find trustworthy suppliers with a good price-quality offer. On this basis we can conclude that the production costs of such a system are in the range of 220 thousand forints and they can be fitted on a large number of electric cars. Given that the charging of a lithium-ion battery is only constant between $10 \%$ and $80 \%$, the calculated values are 


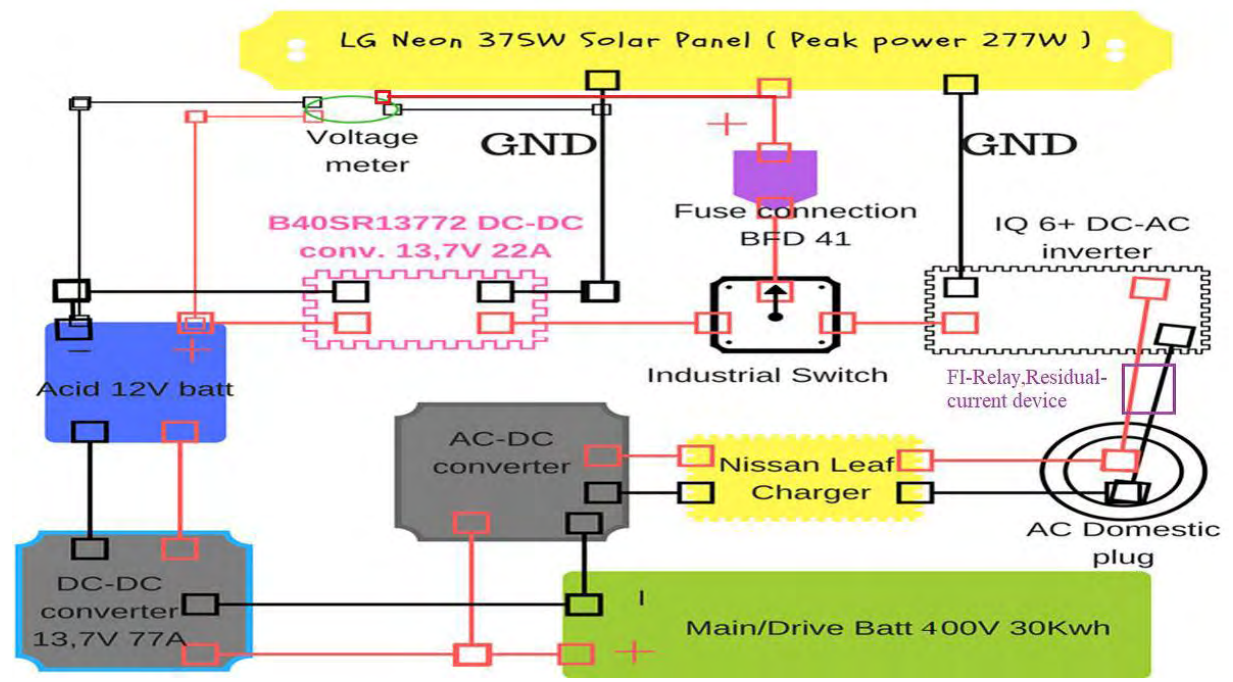

Figure 1. Designed system block scheme [1]

also valid only within this range, but since that's also the range in which urban electric vehicles are used, the entire calculation is only valid between those two values. Since the system gains its extra charge from solar energy, I had to consider the time periods that lack sunlight, for that I used voltage monitoring in order to give the driver precise information about the energy output levels of the system and also the optimal charging method (while parking or during driving). I had to ensure proper contact prevention in order to avoid electric shock. For that I applied a touch protection relay called Fi. This kind of relay is cheap, it reacts quickly so the system will not be damaged which is important because of cost-effectiveness. [1]

\section{Results of the research, considering especially their social and practical applicability}

The system has 2 operating modes: in position 1 , when we turn on the switch, charging is activated, providing energy to an acid battery that supports the 12 Volt systems (radio, lights, heating etc..), thus sparing the main $30 \mathrm{~kW}$ battery from the extra load, this way we can increase the range. In position 2 the main $30 \mathrm{~kW}$ battery is charged but it is only available in parking mode and when the voltage produced by the solar panel is above $16 \mathrm{~V}$. Taking into account, the energy losses, the traffic conditions in Budapest and the $13 \mathrm{kWh}$ consumption of the Nissan Leaf, it can be stated that the system produces the following energy yields per month [2]: (Figures 2., 3. and 4.)

The results above were generated for the planned universal solar charging system, so it can be said that the applied technology can extend the range of the vehicle approximately according the above data. The price of the electricity generated during a year is 11 thousand forints. The Panasonic Solar System implemented in the similarly engineered Toyota Plugin Hybrid uses a $180 \mathrm{~W}$ solar cell that can produce much less power. The system designed by me is more efficient, it is also cheaper and it can be used more widely.

\section{Possibilities for upgrading and devel- opment}

Further improvment can be achieved by means of a better Inverter and more efficient solar panels, which can yield even more energy, expansion of the solar panels also increases the productivity of the system. The switching between charging modes can be replaced by an electric circuit, a so-called comporator for an automatic and more optimized operation. Testing the system in practice would be useful but i could not achieve that without funds. Since we are talking about solar cells, computer simulations can only yield approximate results but since the database was accurate enough, I could easily calculate the yield corresponding to the given conditions. To optimize costs, products from other suppliers can also be considered. 


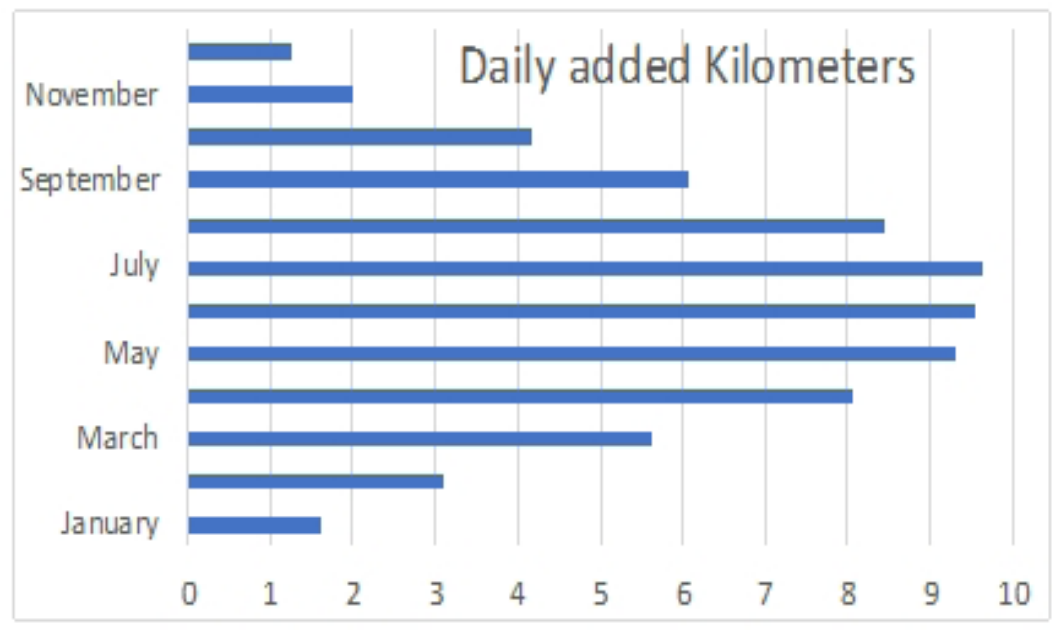

Figure 2. Daily added kilometers in monthly division

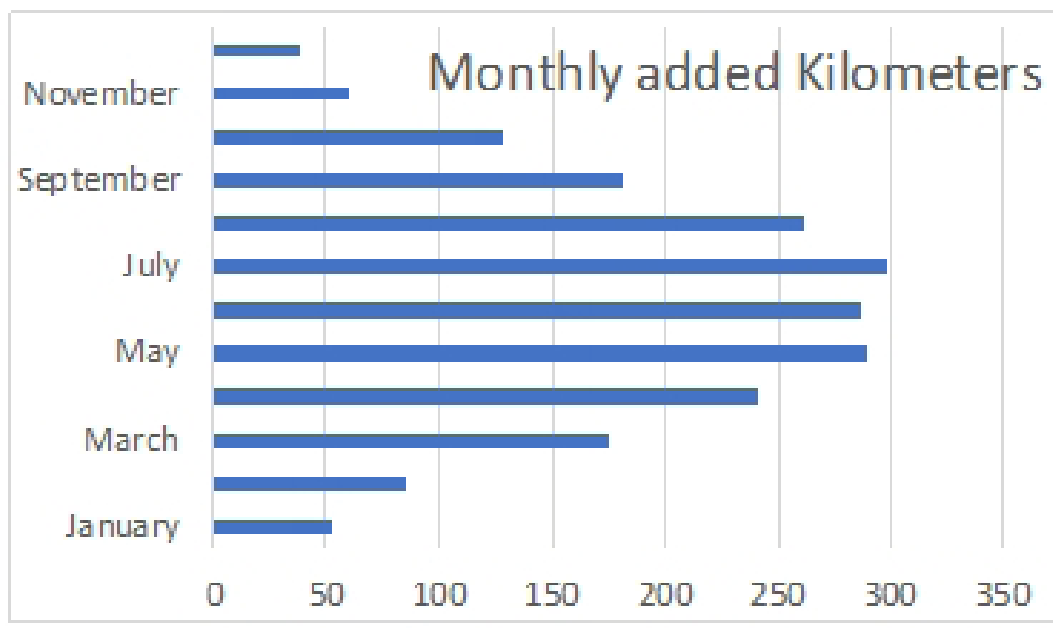

Figure 3. Monthly added kilometers to the system

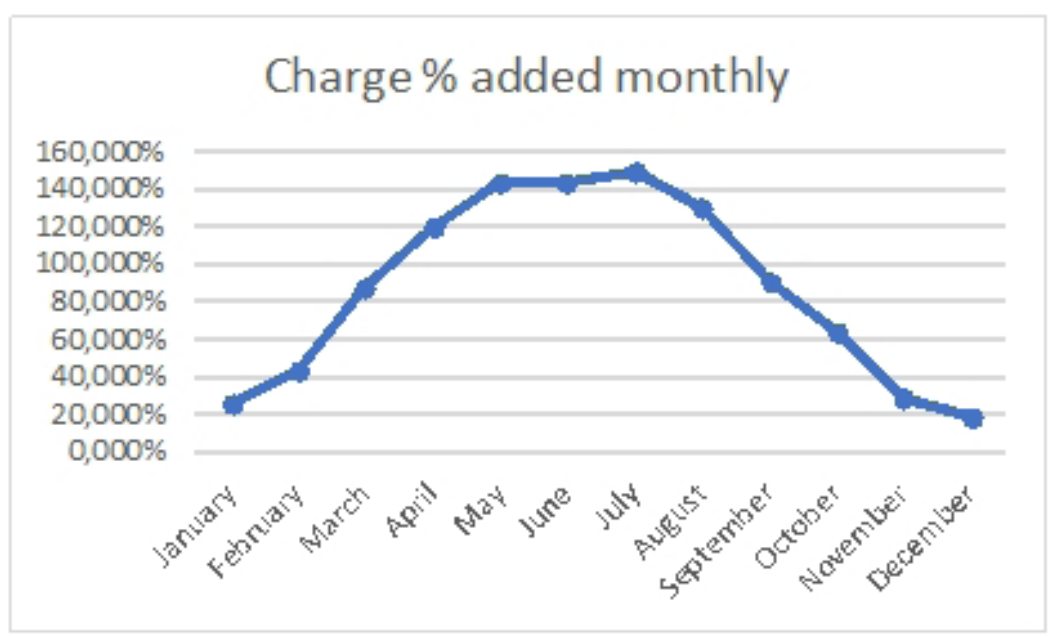

Figure 4. Battery charged in \% monthly 


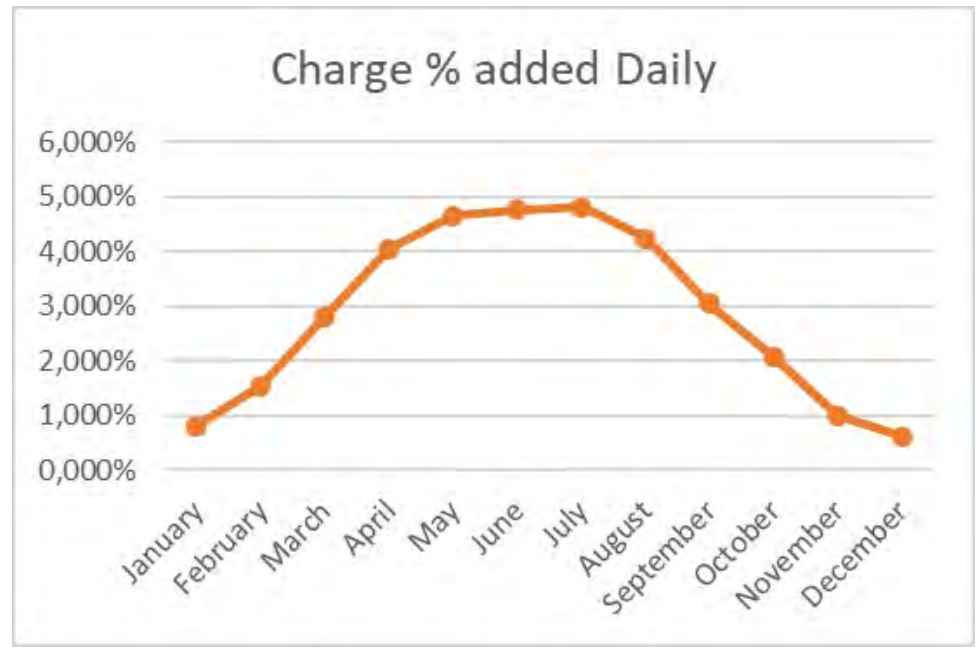

Figure 5. Battery charged in \% daily

\section{Conclusions}

We can summarize that, the designed system can add $5.7 \mathrm{~km}$ to the range of a $30 \mathrm{kWh}$ battery packed Nissan Leaf and that such a system has market potential. The problems that arise from discharge, low range and exclusively stationary charge can be solved by this method because it's a onetime investment that can produce extra electrical energy.

\section{References}

[1] AutoVista Group: Panasonic looking to boost EV range with solar cells on car roofs, Photograph courtesy of Panasonic. (accessed 2017.09.20.) https://www.autovistagroup.com/news-and-insights/panasonic-looking-boost-ev-range-solarcells-car-roofs
[2] Panasonic's Photovoltaic Module HIT ${ }^{\mathrm{TM}}$ adopted for Toyota Motor's New Prius PHV. Press Release, Panasonic Corporation, (accessed 2017.09.20.) http://news.panasonic.com/global/press/ data/2017/02/en170228-3/en170228-3.html

[3] Katona M.: Toyota Prius 1.8 Plug-in Hybrid Executive test. Autonavigatot.hu (accessed 2017.09.18.) https://www.autonavigator.hu/cikkek/nincs-mellebeszeles-08-l100-km-a-tesztfogyasztas/

[4] Battery University: BU-409-Charging Lithium-ion. (accessed 2017.09.20.)

http://batteryuniversity.com/learn/article/ charging_lithium_ion_batteries

[5] J. Huetter: New wrinkle for roof repairs: Panasonic photovoltaic roof for plug-in Toyota Prius. RDN (accessed 2017.09.20.)

http://www.repairerdrivennews.com/2017/03/28/ panasonic-photovoltaic-roof/

[6] Véghely T.: Napelemes rendszerek villamos berendezései. Cser Kiadó, 2014 